\title{
Multigaussian and plurigaussian simulation to quantify uncertainty in estimating ore grades and rock types in copper deposits \\ [Simulación multigaussiana y plurigaussiana para cuantificar incertidumbre en la estimación de leyes de mineral y tipos de rocas en yacimientos cupríferos]
}

Marco Antonio Cotrina Teatino a(iD), Juan Antonio Vega González b(iD). aDepartamento de Ingeniería de Minas, Universidad Nacional de Trujillo, Av. Juan Pablo II s/n, Perú. 'Departamento de Ingeniería Metalúrgica, Universidad Nacional de Trujillo, Av. Juan Pablo II s/n, Perú. *mcotrinat@unitru.edu.pe

Received: 6 January 2022; Accepted: 20 January 2022; Published: 24 January 2022

\section{Resumen}

El principal objetivo de esta investigación fue cuantificar la incertidumbre de un yacimiento de cobre utilizando simulación multigaussiana de leyes y simulación multigaussiana de tipos de rocas. Los algoritmos desarrollados para simulación de variables categóricas, usgsim para variables continuas y algoritmos programados en Python 3.0. Las dimensiones de un bloque son 20x20x15m indexadas $81 \times 109 \times 58$ en xyz; haciendo un total de 512082 bloques. Los resultados de las simulaciones categóricas muestran que existe una probabilidad (p.v. $\geq 0.8$ ) de 19 987, 227 387 y 49036 bloques para roca tipo 1, 2 y 3, respectivamente. En consecuencia, la incertidumbre cuantificada para este umbral $(0,8)$ es del $20 \%$; representando el $58 \%$ de los bloques. Por otra parte, la cuantificación de la incertidumbre de variables continuas (asociadas a leyes de Cu y Mo), no menores a 90,80 y $70 \%$, con base en umbrales de corte de varianza por bloque, dio como resultado la litología One 353, 1900 y 7553 bloques con leyes de $\mathrm{Cu}$, lo que representa $0.07,0.37$ y $1.49 \%$ del total de bloques, respectivamente; un total de 24,139 y 582 bloques con leyes de Mo, que representan el $0.006,0.027$ y $0.114 \%$ del total de bloques; para la litología Dos hubo 106, 648 y 2739 bloques con leyes de $\mathrm{Cu}$, lo que representa $0.021,0.127$ y $0.535 \%$ del total de bloques; un total de 32, 129 y 357 bloques con leyes de Mo, lo que representa el 0.006 , 0.025 y $0.070 \%$ del total de bloques; finalmente para la litología 3 hubo 478, 2324 y 8804 bloques con leyes de $\mathrm{Cu}$, lo que representa el $0.093,0.454$ y $1.719 \%$ del total de bloques; un total de 93 , 355 y 982 bloques con leyes de Mo, lo que representa el $0.018,0.069$ y $0.192 \%$ del total de bloques. Finalmente, se concluye que fue posible cuantificar la incertidumbre en la estimación de leyes minerales y tipos de roca en un yacimiento de cobre.

Palabras clave: Algoritmos; variables categóricas, usgsim; simulación jerárquica, python.

\begin{abstract}
The main objective of this researching was to quantify the uncertainty of a copper deposit using multigaussian simulation of grades of rock types. The developed algorithms for simulation of categorical variables, usgsim for continuous variables and algorithms programmed in Python 3.0.

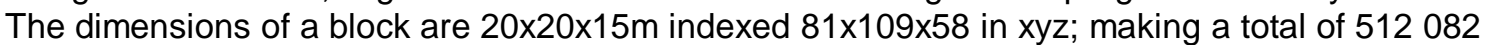
blocks. The results of the categorical simulations show that there is a probability (p.v. $\geq 0.8$ ) of 19 987, 227387 and 49036 blocks for rock type 1, 2 and 3, respectively. Consequently, the quantified uncertainty for this threshold $(0.8)$ is $20 \%$; representing $58 \%$ of the blocks. On the other hand, the quantification of the uncertainty of continuous variables (associated with grades of $\mathrm{Cu}$ and $\mathrm{Mo}$ ), not less than 90,80 and $70 \%$, based on cut-off thresholds of variance per block, resulted in lithology One 353, 1900 and 7553 blocks with $\mathrm{Cu}$ grades, which represents $0.07,0.37$ and $1.49 \%$ of the total blocks, respectively; a total of 24,139 and 582 blocks with grades of Mo,
\end{abstract}




\section{Journal of Sciences and Engineering}

Vol. 6, $\mathrm{N}^{\circ} 1,2022$

representing $0.006,0.027$ and $0.114 \%$ of the total blocks; for lithology Two there were 106, 648 and 2739 blocks with $\mathrm{Cu}$ grades, which represents $0.021,0.127$ and $0.535 \%$ of the total blocks; a total of 32,129 and 357 blocks with grades of Mo, which represents $0.006,0.025$ and $0.070 \%$ of the total blocks; finally for lithology 3 there were 478, 2324 and 8804 blocks with Cu grades, which represents $0.093,0.454$ and $1.719 \%$ of the total blocks; a total of 93,355 and 982 blocks with grades of Mo, which represents $0.018,0.069$ and $0.192 \%$ of the total blocks.

Finally, it is concluded that it was possible to quantify the uncertainty in the estimation of mineral grades and rock types in a copper deposit.

Keywords: Algorithms; categorical variables, usgsim; hierarchical simulation; Python.

\section{Introduction}

Companies that exploit metal and non-metal deposits in the world need geological resources and mineral reserves in order to continue their operations. Geological resources are estimated in quantity (tonnage) and quality (grades or metallic content) through different estimation techniques (Chilès \& Delfiner, 2012). There are two techniques, the traditional ones such as: distance inverse, polygons, profiles or others; and the probabilistic ones such as: simple or ordinary kriging. The latter are good estimators of a value at one site using known values at other sites. However, although the estimation techniques are validated in different ways, they have a lot of error. The foregoing will be verified by means of the following example, a mine that we will call "alpha" plans its exploitation thus determining that at the end of the period, generally annual, it will extract "beta" tons of ore with a "theta" grade. Said "theta" grade translates into metal content sold by the mine, which is seen in economic terms as a NPV. This NPV is never fulfilled in the planned amount, the ideal is that there is a variation of $\pm 10 \%$. However, the variation reaches thresholds of $\pm 35 \%$. Consequently, it makes the mining business critical.

There are certain factors that produce this error in the estimate. One of them and the most important is the little information or the reduced number of samples resulting from the diamond drilling that are available to estimate the ore's grade.

All of the above is based on uncertainty, that is, how much error our estimate of geological resources will have. Estimating uncertainty is no small problem. Today, due to powerful software, simulations can be done that result in millions of simulated values, only one simulation process can deliver values that weigh up to a terabyte.

For this reason, it is necessary to use simulations to be able to quantify the uncertainty. In most geological deposits, the metal of interest is never found alone, but is associated with another metal (with directly or inversely proportional values), which are considered secondary due to their economic value. There are several examples, Blenda $(\mathrm{ZnS})$ with Galena $(\mathrm{PbS})$. For the present study, Copper $(\mathrm{Cu})$ is associated with Molybdenum (Mo).

Mery (2016) carried out a geostatistical modeling of the uncertainty of grades and rock types in a copper deposit to obtain a master's degree in mining, where the quantification of resources was obtained through a multigaussian model for ore grades, loss of fire and granulometry, and to determine rock types I use a plurigaussian model.

\section{Materials and Methods}

The study material consisted of the composite grades of copper, molybdenum and types of rocks from the copper deposit.

This research work describes the cascade simulation methodology, using simulation algorithms for categorical variables, for continuous variables (Usgsim) and algorithms programmed in Python 3.0 as well as executables from the GSLib library; both are free version. 


\section{SE \\ Journal of Sciences and \\ Engineering}

Vol. 6, $\mathrm{N}^{\circ}$ 1, 2022

Copyright (c) 2022, CINCADER.

ISSN 2523-9503

DOI: https://doi.org/10.32829/sej.v6i1.157

\section{CINCADER}

Centre of Research and Training for

Regional Development

Online at www.journals.cincader.org

The simulation made it possible to quantify the uncertainty associated with not knowing the real values of a regionalized variable, through the construction of various scenarios (number of realizations).

The model consists of the following steps of the simulation algorithms:

- EDA; Figure 1(a)

- Anamorphosis / coding of the original data; Figure 1(b)

- Bigaussian test; Figure 1(c)

- Variographic models on the transformed data of continuous variables; Figure 1 (d), (e) and (f)

- Variographic models on the transformed data of discrete variables; Figure $1(\mathrm{~g})$ and $(\mathrm{h})$

- Simulation, Figure 1 (i).

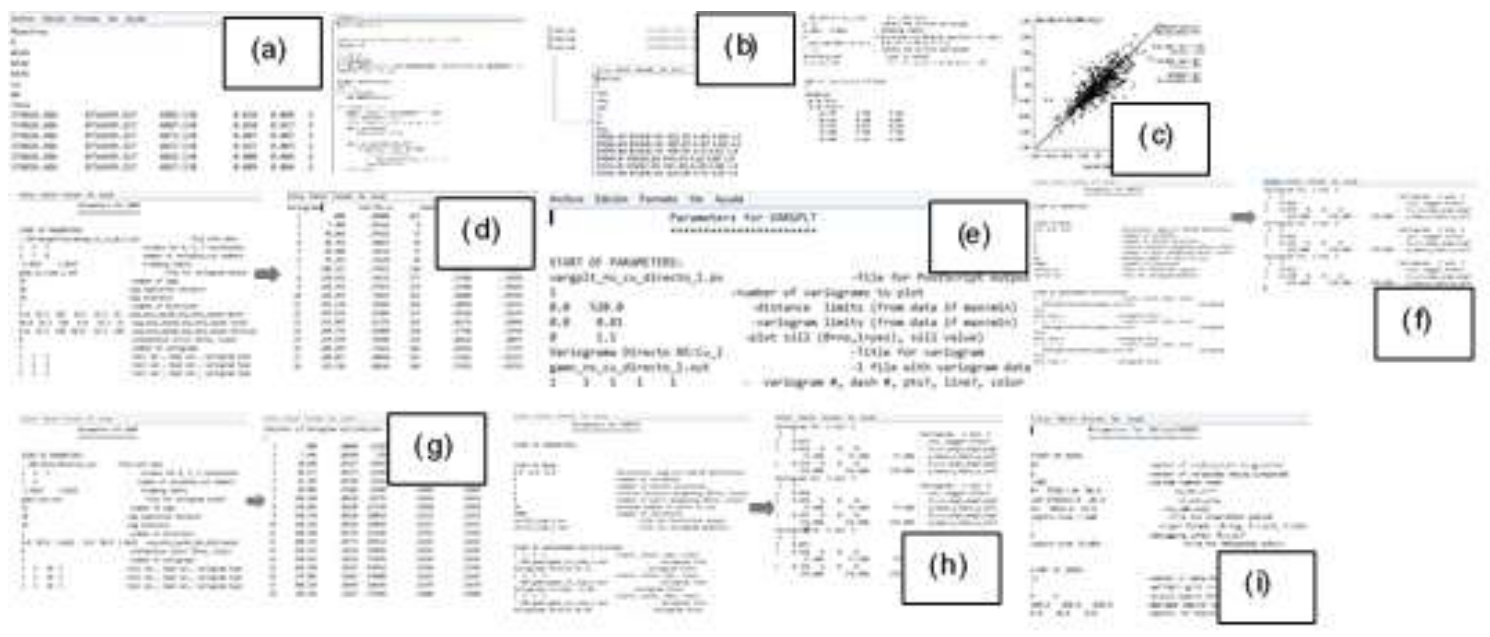

Figure 1. Research development process with executables/codes. (a) Data (composite sample formats); (b) Dofile (Algorithm that separates data into geological categories); (c) Nscore (continuous variable transformation and correlation clouds; (d) Gamv (Algorithm for calculating direct and crossed variograms); (e) Vargplt (Code for displaying variograms); (f) Varfit (Algorithm for modeling variograms); (g) Gamv (Code to generate indicator variograms), (h) Varfit (Algorithm to model indicator variograms) and (i) Usgsim (parameters to simulate grades).

\section{Results}

\section{Statistical analysis of composite samples}

In Table 1, the descriptive statistics of the grades of copper and molybdenum composites at 15 meters length are presented. In total there are 5625 data where the maximum grade for copper is 2.949 and for molybdenum it is 0.237 . In Table 2, the number of blocks with lithologies (or rock types) 1,2 and 3 is observed, it is observed that rock 2 has $55.74 \%$.

Table 1. Statistics of copper and molybdenum grades

\begin{tabular}{cccccccc}
\hline & No Data & Maximum & Minimum & Mean & Variance & Kurtosis & $\begin{array}{c}\text { Standard } \\
\text { deviation }\end{array}$ \\
\hline $\mathrm{Cu}$ & 5625 & 2.949 & 0.002 & 0.430 & 0.084 & 2.733 & 0.290 \\
$\mathrm{Mo}$ & 5625 & 0.237 & 0.001 & 0.015 & 0.000 & 20.706 & 0.017 \\
\hline
\end{tabular}




\section{Journal of Sciences and \\ Engineering}

Vol. 6, $\mathrm{N}^{\circ} 1,2022$

Table 2. Statistics of rock types

\begin{tabular}{|c|c|c|}
\hline Type & $N^{\circ}$ Blocks & Percentage (\%) \\
\hline Rock 1 & 61155 & 17.30 \\
\hline Rock 2 & 197032 & 55.74 \\
\hline Rock 3 & 95303 & 26.96 \\
\hline
\end{tabular}

\section{Histograms of copper and molybdenum grade}

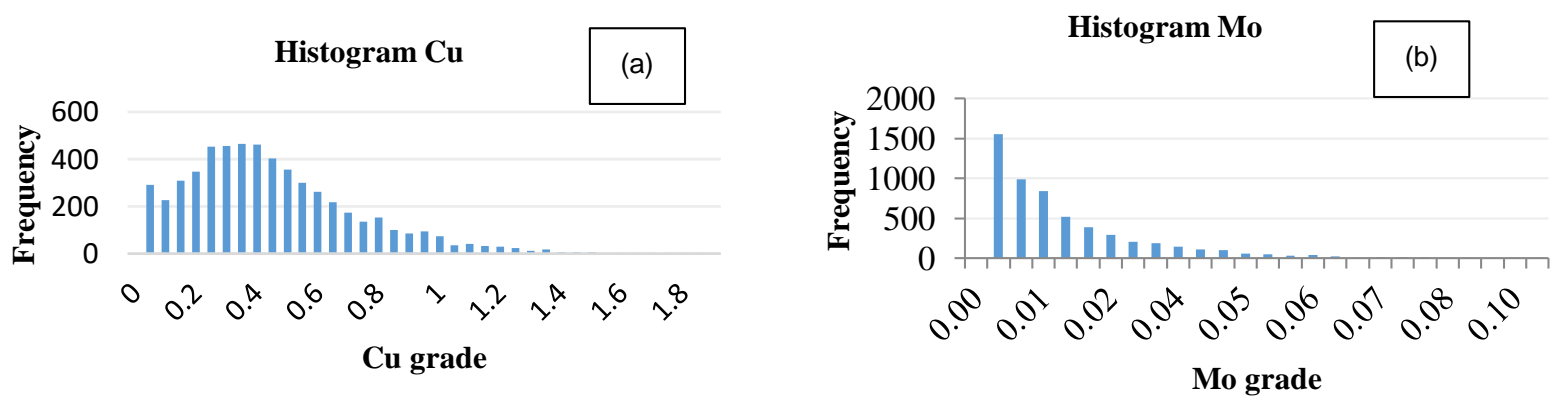

Figure 2. (a) copper grade histogram and (b) molybdenum grade histogram

Transformation of regionalized variables to Gaussian variable

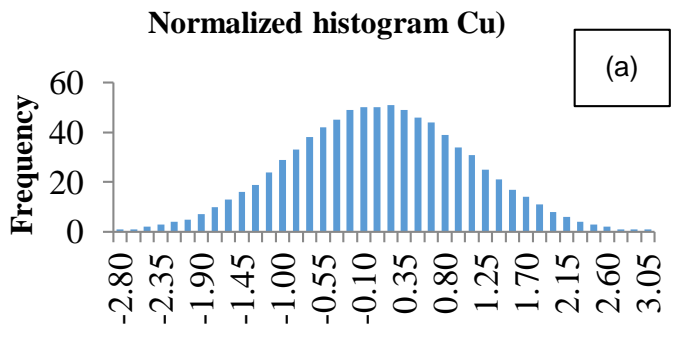

Cu grade

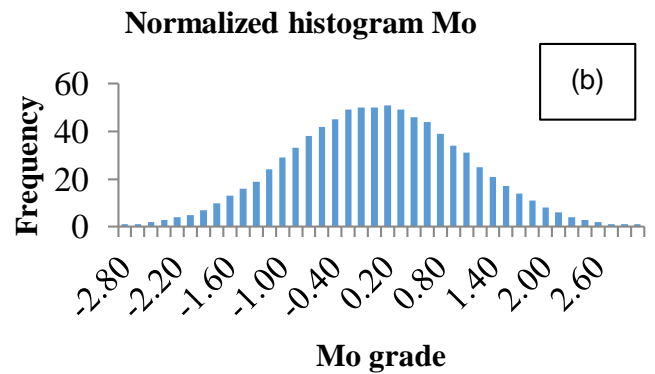

Mo grade

Figure 3. (a) normalized copper grade histogram and (b) normalized molybdenum grade histogram (anamorphosis)

In Figure 2, the distributions of copper and molybdenum grades are observed, with a positive asymmetry coefficient, and in Figure 3, the distribution of normalized $\mathrm{Cu}$ and Mo grades is shown; The foregoing is done with the purpose of transforming the regionalized variable into Gaussian data in order to continue with the study.

The application of anamorphosis of $\mathrm{Cu}$ and Mo grades, allowed normalizing the regionalized variables transforming them into Gaussian variables since the multigaussian model requires that the spatial distribution of the random function be Gaussian (Figure 3), as indicated by Journel \& Huijbregts (1978) and Dunn (2011). 


\section{SE}

Vol. 6, $\mathrm{N}^{\circ} 1,2022$

\section{Journal of Sciences and \\ Engineering}

Copyright @ 2022, CINCADER.

ISSN 2523-9503

DOI: https://doi.org/10.32829/sej.v6i1.157

\section{Bigaussianity test and variographic analysis}
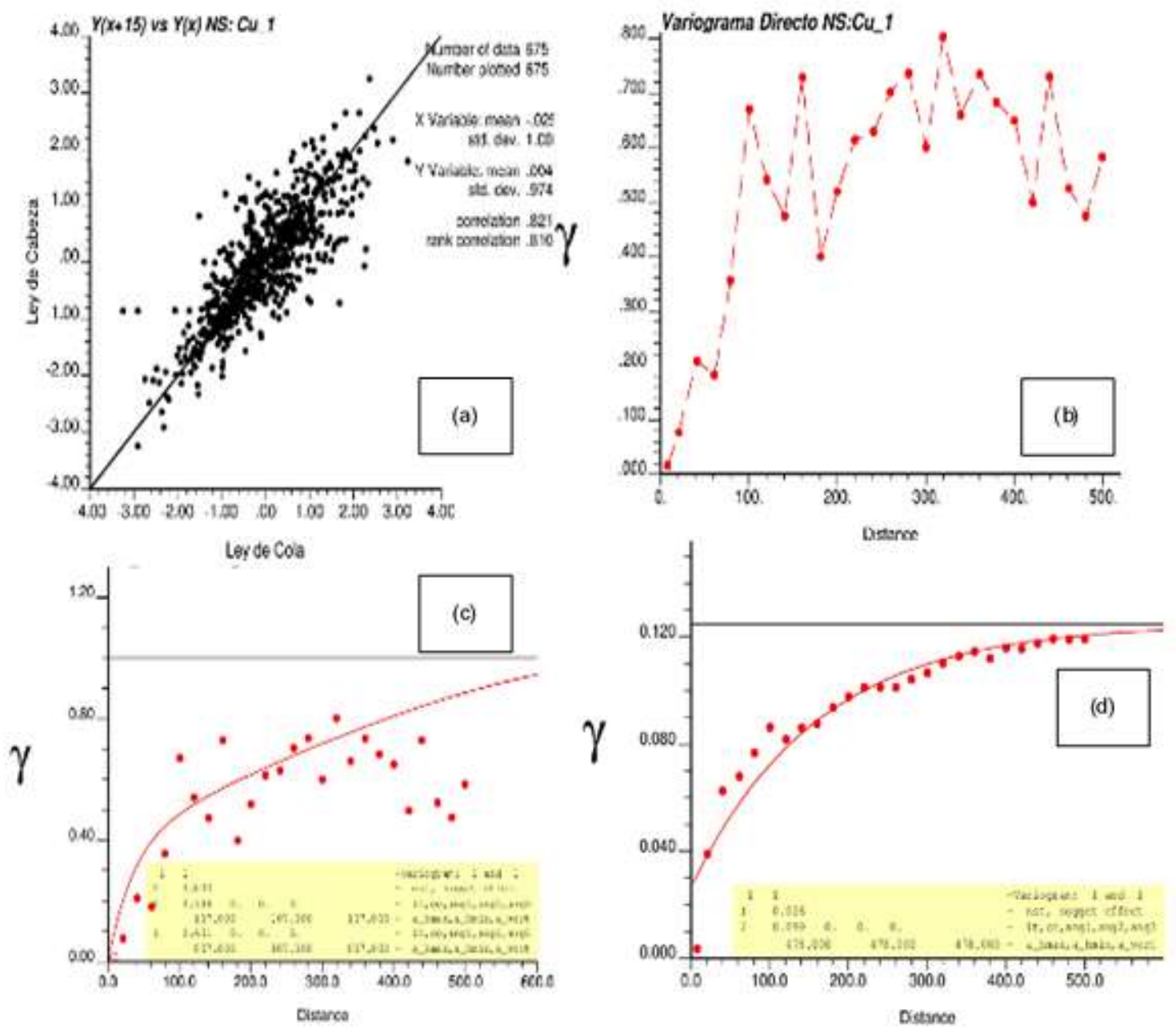

Figure 4. (a) Bigaussianity test; (b) Experimental variogram with normalized copper grades; (c) Modeled variogram of normalized copper grades and (d) Experimental indicator variogram and modeled for rock type 1 .

In Figure 4, (a) you can see the spatial correlation cloud of the transformed grades of copper for the geological domain of rock type 1. This is corroborated by a positive slope. As is known, correlation clouds are one of the Bigausianity tests, described by Sucapuca (2018). Figure 4. (b) shows the experimental directional variogram for copper, a geostatistical tool that allows us to know the spatial continuity of the variable of interest. Figure 4. (c) shows the modeled variogram for the copper grade in rock 1. Figure 4. (d) shows the variogram of indicators for rock 1. 


\section{Journal of Sciences and Engineering}

Vol. 6, $\mathrm{N}^{\circ} 1,2022$

Simulation of categorical variables (rocks 1, 2 and 3; first 4 scenarios of 20), Cu and Mo grades
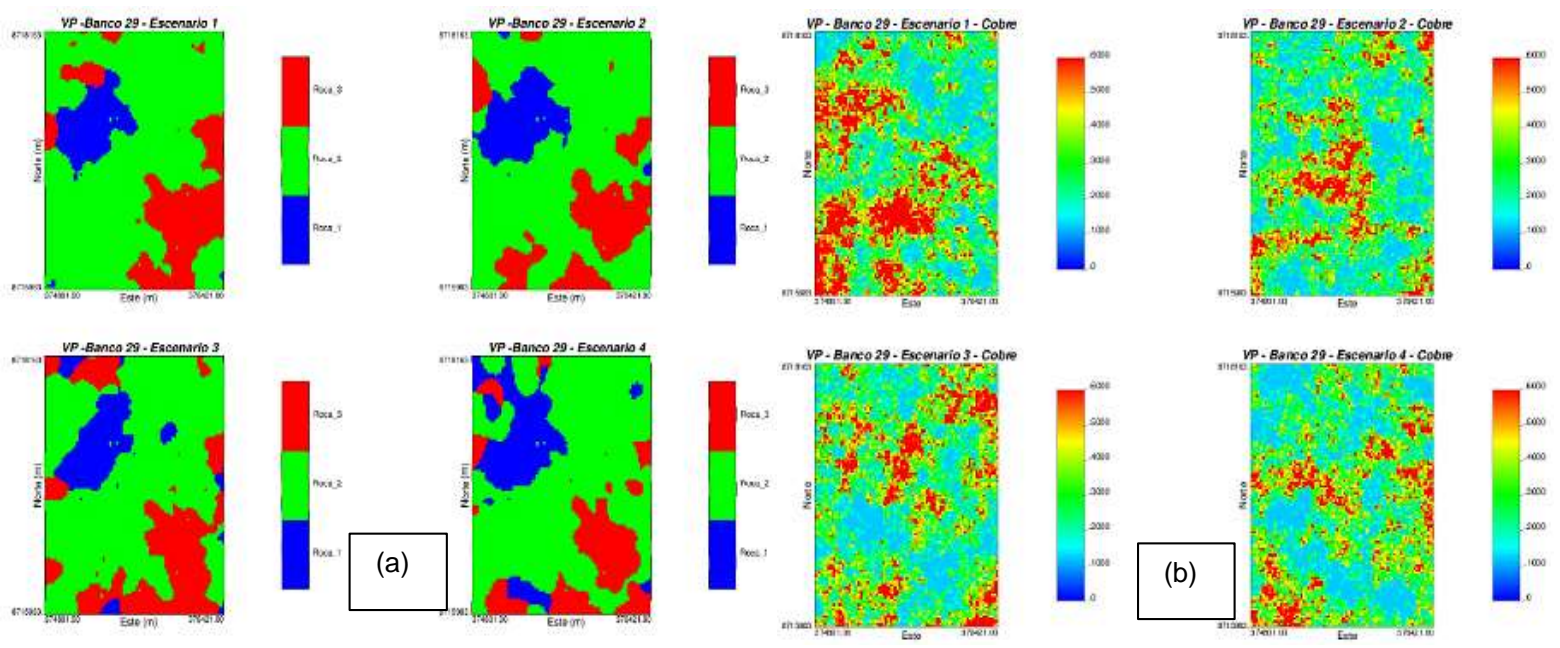

Figure 5. (a) Simulation of rock types 1,2 and 3; (b) Simulation of copper grades

Figure 5. (a) shows the three types of simulated rocks, taking from this figure four scenarios out of 20 (executions) in bank 29, whose figures show great correlation and a greater proportion of domain 2 (rock type 2). The results are consistent with what was done (Yunsel \& Ersoy, 2013; Mery, 2016). In Figure 5. (b) the simulations of copper grades are observed, taking from this figure four scenarios of 20 (realizations) in bank 29. In Figure 5. (c) the simulations of molybdenum grades are observed, taking from this figure four scenarios of 20 (realizations) in bank 29.

\section{Category proportions by scenarios (realizations) and probability by rock type}
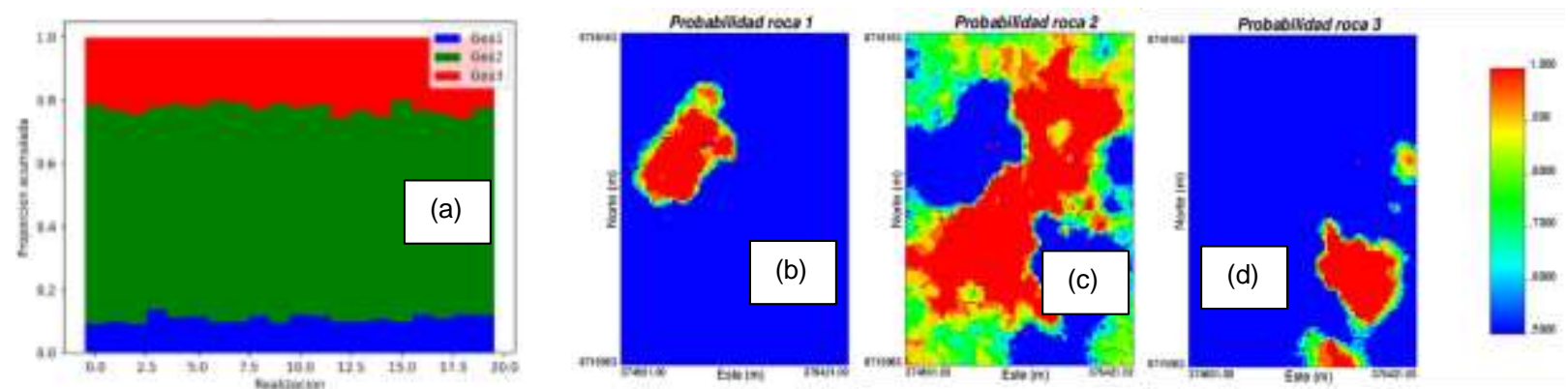

Figure 6. (a) Categorical proportion (rock type) in the 20 realizations; (b) Maximum probability in rock 1; (c) Max Chance on Rock 2 and (d) Max Chance on Rock 3.

In Figure 6 (a) the proportion according to the domain in each realization (scenario) is observed, clearly rock type 2 has a greater dominance over the other rock types, followed by rock type 3 and finally in lesser proportion. type 1 rock (Portilla Lazo, 2018; Díaz \& Casar, 2009; Gálvez \& Emery, 2012; Mery, 2016). Figure 6 (b) shows the probability of occurrence for rock 1, red color maximum probability and blue color very little probability (rock 2 and 3). Figure 6 (c) shows the probability of occurrence for rock 2 , red color maximum probability and blue color very little probability (rock 1 and 3 ). Figure 6 (d) shows the probability of occurrence for rock 3 , red color maximum probability and blue color very little probability (rock 1 and 2). 


\section{SE \\ Journal of Sciences and Engineering}

Vol. 6, $\mathrm{N}^{\circ}$ 1, 2022

Copyright @ 2022, CINCADER.

ISSN 2523-9503

DOI: https://doi.org/10.32829/sej.v6i1.157

\section{Uncertainty according to the probability of rock type}

For categorical variables (geological domain), 20 realizations (scenario) were simulated, whose probabilities of occurrence are shown in Table 3 , where different cut-off thresholds or probability value $(\mathrm{pv})$ greater than or equal to $0.75,0.80,0.85,0.90,0.95$ and 1 with associated uncertainty of $0.25,0.20,0.15,0.10,0.1$ and 0.00 , respectively. The above, delivered different amounts of block occurrence being $35,743,21,996,19,987,18,032,16,044,14,044$ and 11,139 blocks for rock type 1.

Table 3. Probability and uncertainty in rock type 1

\begin{tabular}{lccc}
\hline Probability rock type 1 & Quantity & Percentage & Uncertainty (\%) \\
\hline Total blocks & 35743 & & \\
$P v=>0.75$ & 21996 & 61.54 & 25 \\
$P v=>0.80$ & 19987 & 55.92 & 20 \\
$P v=>0.85$ & 18032 & 50.45 & 15 \\
$P v=>0.90$ & 16103 & 45.05 & 10 \\
$P v=>0.95$ & 14044 & 39.29 & 5 \\
$P v=>1.00$ & 11139 & 31.16 & 0 \\
\hline
\end{tabular}

\section{Uncertainty in fine copper and molybdenum content}

The quantification of the uncertainty was established based on the variance of the $\mathrm{Cu}$ and Mo grades for each block, establishing 10 cut-off thresholds, where the greatest variability is represented by the highest variance thresholds, for an uncertainty not less than $90 \%$. , 80 and $70 \%$, there are 353,1900 and 7553 blocks with grades of $\mathrm{Cu}$, which represents $0.06893,0.37123$ and $1.49440 \%$ of the total blocks; a total of 24,139 and 582 blocks with Mo grades, representing $0.00569,0.02714$ and $0.11365 \%$ of the total blocks, in rock 1 .

Table 4. Uncertainty in estimating copper and molybdenum grades based on their grade variance in the block for type 1 rock.

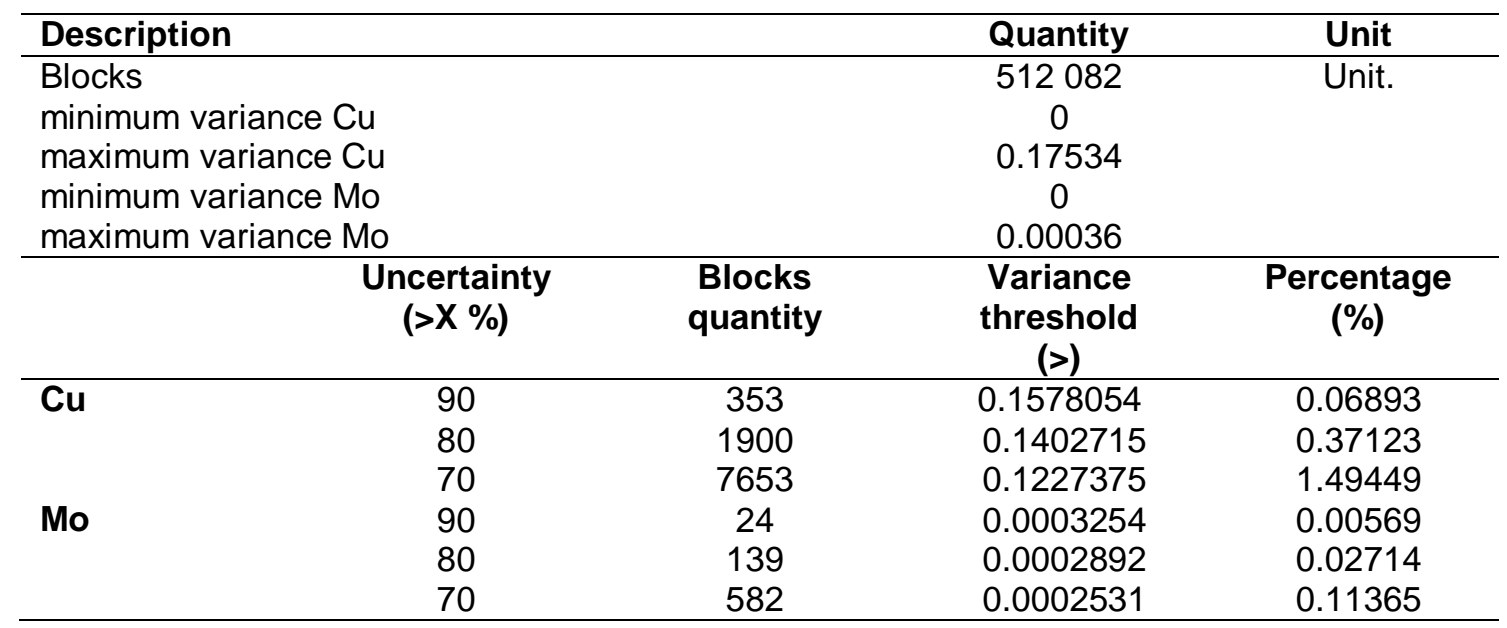




\section{Journal of Sciences and Engineering}

Vol. 6, $\mathrm{N}^{\circ} 1,2022$

Copyright @ 2022, CINCADER.

ISSN 2523-9503

DOI: https://doi.org/10.32829/sej.v6i1.157

\section{Conclusions}

The present work was able to quantify the uncertainty of a copper deposit through multigaussian simulation in three lithological domains, whose results show that, when the uncertainty is low, the probability of occurrence of a type of rock is high; however, the estimated total tonnage decreases, in the case of the $\mathrm{Cu}$ and Mo grades, a plurigaussian simulation was performed, quantifying the uncertainty of blocks not less than 90,80 and $70 \%$.

The present research project was able to determine the lithological domains for each variable of interest, $\mathrm{Cu}$ and Mo grades. The deposit has 3 geological domains (rock type 1,2 and 3), facilitating its analysis and simulation. Twenty scenarios were considered, showing a clear relationship between them, whose results also show a relationship in each scenario by lithology, with higher grades in domains 2 and 3 (rock type 2 and 3 ).

The research managed to quantify the uncertainty in each domain, for a p.v. $\geq 0.8$ with an uncertainty of $20 \%$. Above this threshold, the number of blocks obtained is $19,987,227,387$, and 49,036 for each domain (rock type 1,2, and 3), respectively. The quantification of the uncertainty associated with grades of $\mathrm{Cu}$ and Mo based on cut-off thresholds of their variance per block resulted in lithology One of 353, 1900 and 7553 blocks with grades of $\mathrm{Cu}$, which represents $0.06893,0.37123$ and $1.49440 \%$ of the total blocks; a total of 24,139 and 582 blocks with Mo grade, representing $0.00569,0.02714$ and $0.11365 \%$ of the total blocks; for lithology two there were 106, 648 and 2739 blocks with grades of $\mathrm{Cu}$, which represents $0.02070,0.12657$ and $0.53487 \%$ of the total blocks; a total of 32,129 and 357 blocks with Mo grades, which represents $0.00644,0.02539$ and $0.06972 \%$ of the total blocks; finally, for lithology 3 , there were $478,2,324$, and 8,804 blocks with Cu grades, which represents $0.09334,0.45383$, and $1.71926 \%$ of the total blocks; a total of 93,355 and 982 blocks with Mo grades, which represents $0.01816,0.06932$ and $0.19177 \%$ of the total blocks, this represents an uncertainty of not less than 90,80 and $70 \%$, respectively.

\section{Acknowledgments}

Special thanks to Dr. Mauricio Garrido, academic from the University of Chile, for his extraordinary support in the development of this research.

\section{References}

Díaz Viera, M., \& Casar González, R. 2009. Geoestadística aplicada: Métodos de simulación. México: Repositorio Institucional Universidad Nacional Autónoma de México.

Dunn, R. 2011. Plurigaussian Simulation of rocktypes using data from a gold mine in Western Australia. Australia: Edith Cowan University.

Gálvez, I., \& Emery, X. 2012. Modelamiento geoestadístico de mineralogías de sulfuros en un yacimiento de cobre. Santiago de Chile: Repositorio Institucional Universidad de Chile.

Journel, A., \& Huijbregts, C. 1978. Mining geostatistics. Academic Press, London.

Mery, N. 2016. Modelamiento geoestadístico de la incertidumbre en leyes y tipos de roca en un yacimiento ferrífero. Repositorio de tesis Universidad de Chile, 1-140. 


\section{Journal of Sciences and Engineering}

Vol. 6, $\mathrm{N}^{\circ} 1,2022$

Copyright @ 2022, CINCADER.

ISSN 2523-9503

DOI: https://doi.org/10.32829/sej.v6i1.157

Portilla Lazo, C. A. 2018. Modelo geoestadístico integrado a partir de la interpretación de datos de pozos para un campo petrolero ecuatoriano. Lima: Institutional Repository, Universidad Nacional Mayor de San Marcos.

Sucapuca Pacara, L. E. 2018. Evaluación Geoestadística de las Relaciones de Contacto entre Unidades Geológicas y Variogramas de sus Indicadores. Arequipa: Institutional Repository, Universidad Nacional San Agustín de Arequipa.

Yunsel, T., \& Ersoy, A. 2013. Geological modeling of rock type domains in the Balya (Turkey) lead-zinc deposit using plurigaussian simulation. Central European Journal of Geosciences, 5(1) 77-89. https://doi.org/10.2478/s13533-012-0113-z. 